\title{
Workers' flexible working arrangement and productivity in ABC semiconductor company
}

\author{
Alzona, Wilfred David M. \\ Laguna College of Business and Arts, Philippines (bmalzona@gmail.com) \\ Villapando, Melchor A. \\ Laguna College of Business and Arts, Philippines (m.villapando@lcba.edu.ph)
}

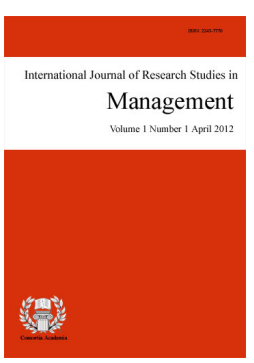

ISSN: 2243-7770

Online ISSN: 2243-7789

Received: 5 August 2021

Revised: 8 August 2021 DOI: $10.5861 /$ ijrsm.2021.m056

Accepted: 9 August 2021

OPEN ACCESS

\begin{abstract}
This study determined the level of implementation of workers' flexible working arrangement and the extent of the worker's productivity level in ABC Semiconductor Company. The descriptive correlational method was utilized, and the respondents were the Department Manager and Rank-and-File employees. The researcher used a survey questionnaire and a simple mean and four-point Likert scale, Pearson product moment correlation and regression analysis were used for its statistical treatment. A descriptive correlational research design was used. This study was focused on determining the significant relationship between the level of implementation of workers' flexible working arrangement and the extent of the worker's productivity level in ABC Semiconductor Company. Purposive random sampling was used in selecting 270 respondents comprising 30 managers and 240 rank-and-file which is $50.6 \%$ of the total population. Survey questionnaire was utilized to gather necessary data. It was subjected to validation from the experts and underwent Cronbach reliability testing. Using weighted mean, it was determined that $\mathrm{ABC}$ Semiconductor company evidently implemented workers' flexible working arrangement in the Normal Operations and Development Plans. Likewise, there was a high worker's productivity level in in ABC Semiconductor as to employees Performance against Objectives and Values-based Behavior and very high productivity level as to Attendance and Punctuality. The result revealed that implementation of workers' flexible working arrangements was associated or connected to the extent of worker's productivity level in terms of performance against objectives and values-based behavior. The higher the implementation of the workers' flexible working arrangements, the higher the worker's productivity level and vice versa. Moreover, the study showed that the implementation of Flexible Working Arrangement Specifically Development Plans has significant effect on the Workers' productivity in terms of Values-based Behavior. The implementation of FWA was contributory to the work productivity of the employees. Proposed action plan was crafted to improve the Flexible Working Arrangement Implementation of the ABC Semiconductor company and to encourage its employees to perform their duties to their utmost ability through different programs and activities.
\end{abstract}

Keywords: flexible working arrangement, workers' productivity, normal operations, development plans, performance against objectives, values-based behavior, attendance and punctuality 


\section{Workers' flexible working arrangement and productivity in $\mathrm{ABC}$ semiconductor company}

\section{Introduction}

Remote work is the new truth, and transactional work has grown exponentially, provided by freelancers, contract workers or consultants. By 2020, as much as half of the labor force is forecast to function individually and virtually. Most companies are also dealing with how to handle their virtual workers effectively and how to help and empower them effectively - an increasingly urgent challenge as more Millennials enter the workforce, adding job satisfaction with changed attitudes (Hoefling, 2017). Thus, flexible work arrangements have been found to improve attraction and retention, and have also been linked to a variety of positive organizational and individual outcomes.

With that, Villaraza and Angangco (2020) stated that the COVID-19 pandemic is causing a shift in paradigm in how work is done in the Philippines. Whereas before long hours of stay in the office was the norm, the imposition of the Enhanced Community Quarantine ("ECQ") forced employers of non-essential industries to recognize that work can be done even outside the office premises, such as through Work-From-Home ("WFH") arrangements. These WFH arrangements have been widely embraced and are expected to linger even after the ECQ has been lifted. There is, thus, a primordial need to understand how WFH arrangements fit in the labor law landscape and how they should be legally implemented.

This is when the objective of the study takes place. There are several forms of guiding, but ten acts will form a route to emerge stronger from the crisis, regardless of the type of company or geography. Beginning with an idea that returning is a muscle that needs to be exercised, not a plan to be carried out once or a date to be accomplished. Companies need to move on to more concrete factors, such as the need to make major moves quickly and to be prepared to reconsider whole portfolios, including where work is done. One best call for change here is the Flexible Work Arrangements, where employees will lessen their contact to many people in a period of time while keeping the quality of work wherever he/she is working. By this, although, the vaccines are not yet fully distributed to the entire population of the Philippines, perhaps, the virus are still contained through the collaboration of the industries by this arrangement while waiting for the bulk vaccination not only in the first-world and rich countries but also worldwide including Philippines.

\subsection{Theoretical Framework}

The study is anchored on three theories. The Goal-Setting Theory of Edwin Locke, Expectancy Theory of Dr. Victor H. Vroom and Theory of Adaptability. Goal setting involves the conscious process of establishing levels of performance to obtain desirable outcomes. It is based on the premise that much human action is purposeful, in that it is directed by conscious goals. One of the conditions of the goal-setting theory is self-efficacy or the belief that one can attain their goal (Weaver, 2016). Locke and Latham (2006) explained that goal is an aim of action that needs to be consciously gained and achieved. It involves the different levels of goal difficulty, levels of performance, and the number of efforts that have been putting in to obtain the desired outcomes. Besides, to order to obtain effective performance, some conditions should be met which including goal specificity, goal difficulty, goal acceptance and commitment, and feedback.

In the same manner, Expectancy theory states that people are motivated to do something because they think their actions will lead to their desired outcome. It proposes that work motivation is dependent upon the perceived association between performance and outcomes and individuals modify their behavior based on their calculation of anticipated outcomes. The theory also states that individuals have different sets of goals and can be motivated if they believe that: there is a positive correlation between efforts and performance; favorable performance will

14 Consortia Academia Publishing (A Partner of Tourism Educators and Movers of the Philippines) 
result in a desirable reward; and the reward will satisfy an important need (Weaver, 2016).

Last, the theory of Adaptability as described by Anderman \& Sinatra (2012), the current pace of change in a New Normal is unprecedented in human history. To name one, it took Darwin 26 years to write The Origin of Species to propose his theory on biological change (Mayr, 1991). This statement reflected the role of the employees both in the management and rank-and-file to recognize the need to change and the willingness to change one's thinking to surpass challenges in the workplace of Semiconductor company and to view the opportunities that lie ahead, and hence adaptability to the call of change in a new normal can be anchored in this study

\subsection{Conceptual Framework (Research Paradigm)}

INDEPENDENT VARIABLE

\begin{tabular}{|c|c|}
\hline Level of Implementation of & Level of Worker's Productivity \\
\hline Workers' Flexible & \\
\hline Working Arrangement & - Performance against objectives \\
\hline - Normal Operations & - Values-based Behavior \\
\hline - Development Plans & - Attendance and Punctuality \\
\hline
\end{tabular}

Figure 1. Research Paradigm

\section{DEPENDENT VARIABLE}

Level of Worker's Productivity

Performance against objectives

- Attendance and Punctuality

As shown in the Figure 1 the first box contains the Independent Variable (IV) which is the Level of Implementation of Workers' Flexible Work Arrangement in two parts namely, its normal operations and the development plans that can be made by the workers/employees. These two parts play a major role on how the arrangement of works to be done according to position/designation of the employee in the Semiconductor company. The second box presents the Dependent Variable (DV) which is affected by the Independent Variable. It is the productivity of the workers which will be measured according to three areas such as performance against the objectives, values-based behavior and attendance and punctuality.

\subsection{Statement of the Problem}

The main objective of the study is to create a Strategic Action Plan in the Productivity of Semiconductor Company through Flexible Working Arrangements of Workers. Specifically, it seeks to answer the following questions:

$>\quad$ What is the level of implementation of workers' flexible working arrangement as assessed by Department Manager and Rank-and-File in terms of: Normal operations and Development Plans?

$>$ To what extent is the worker's productivity level in ABC Semiconductor Company in terms of: Performance against objectives, Values-based behavior, and Attendance and Punctuality?

$>\quad$ Is there a significant difference between the assessments of the two groups of respondents in terms of the level of implementation of workers' flexible working arrangement and the extent of worker's productivity level?

$>\quad$ Is there a significant relationship between level of implementation of workers' flexible working arrangements and productivity in ABC Semiconductor Company?

$>$ Do flexible working arrangements singly or in combination significantly impact the worker 
Alzona, W. D. M., \& Villapando, M. A.

productivity in $\mathrm{ABC}$ Semiconductor Company?

$>$ Based on the findings of the study, what action plan may be proposed?

\subsection{Hypotheses}

The relationship of the variables was analyzed, and the hypothesis given reflected the existence or nonexistence of such a relationship. The researcher aimed to prove or disprove the following hypothesis:

$>$ There is no significant difference between the responses of the two groups of respondents regarding the assessed variables.

$>$ There is no significant relationship between the workers' flexible working arrangement and productivity.

$>$ Workers' flexible working arrangements do not impact workers' productivity.

\subsection{Scope and Delimitation}

The main scope of the study focuses on the comparison of the assessments made by the two groups of respondents' flexible working arrangements in the ABC Semiconductor Company. A correlation of the extent of level of implementation of FWA and the productivity rate of the workers. Specifically, the respondents are the managers and rank-and-file in ABC Semiconductor Company will be intended to be accomplished within 2021 . The results of this study will be based on the answers indicated on the questionnaire to partake on this study. The study limits itself to the use of purposive sampling due to availability, criteria presented in the study to be included as the respondents and the willingness of the respondents to partake on the study. Given a limited time, the study also limits itself to have a proposed enhanced action plan as an output. The proposed action plans need to be evaluated until such time that it will be fully accepted as a proposed plan for the FWA implementation until it is needed in the New Normal context.

\section{Review of Related Literature and Studies}

Uglanova and Dettmers (2018), Lott (2020), Worklogic (2020), and Sharafizad (2011) all agree that flexible working arrangements is indeed helpful and healthy in the well-being of the workers for they deliver higher than what is expected in this kind of work arrangement. Work schedule variations that depend on the employees' needs and situation will most likely to result to higher productivity rate than those recommended and fixed schedules given by the heads of the organizations. Furthermore, the papers written by Jain (2019), Holmes and Oldham (2019), and Maheshwari and Vohra (2018) all argued that proper, concise, precise, and accurate training and development programs for employees result to positive correlation to employees' higher productivity rate. Also, the three papers established training and development may seem to be successful if it is aligned with the goals, objectives, and vision, and mission of the organization.

In addition, the similarities found in these several authors including Bakshi (2020) and Sharafizad et al., (2011) were believed that flexible work will become the new normal, particularly as the crush of commuting rises in cities and the barriers to remote working are removed by technology. Now, as the new normal was embraced a similar definition and how FWA has to be done were defined by the following authors including Aten (2020), Worklogic (2020), GoBusiness (2020) in which they mentioned that that Americans won't be interested in going back to work, either. They're not really enthusiastic, at least, about going back to work in an office. 54 percent of Americans want to keep remote work as their primary mode of work, according to the survey, and 70 percent claim they would at least like it to be an option.

Eventually, Philippines will do likewise not unless, massive vaccination were implemented across all over the country. With these new realities setting in, it becomes important to learn how to calculate efficiency while

16 Consortia Academia Publishing (A Partner of Tourism Educators and Movers of the Philippines) 
working from home. In a nutshell, these performance metrics are required: call volume measurement, positive feedback rate tracking, conversion rates monitoring, 180-degree feedback collection, weekly sprint adherence rate, and variance estimation of the schedule. In order to improve efficiency and reduce burnouts, versatility is given priority when allowing remote work and ensuring connectivity and collaboration by maintaining a sufficient remote stack. If companies learn to virtually control efficiency, there will be no going back for good and for good.

However, the differences occur on the nature of the work since some of the authors like Kessler (2017) and GoBusiness (2020) conducted studies in academic institutions and telecommunications but will be implemented in the ABC Semiconductors company in which a little twist and manipulation of the FWA will be implemented specially in the normal operations and development plans of the ABC Semiconductors company. More so, the similarities found in three different authors including Neill, Harcourt and Truity (2020), they defined the normal operations what a semiconductor company does. From the nature of a semiconductor industry, down to the functions of every stakeholder operated in it in which played a major role in the study since the FWA to be done has something to do with how normal operations work even in a remote work arrangement.

Eventually, what is common to both Gleese and Reese (2017) were the productivity of the workers not only through knowledge and skill but also the values-based behaviors they acquire in the workplace. They mentioned that business ethics, discipline, sincerity and dedication must be performed by doing the right things at all times and in all circumstances even when no one is watching/looking. Takes accountability for commitment by admitting honestly to making mistakes, learning from and accepting responsibility for the consequences of own actions while in a remote place from work. Nonetheless, these similarities and differences can help the study to improve FWA and productivity not only in the ABC Semiconductors company but eventually to any nature of businesses and institutions requiring FWA in the New Normal.

\section{Methodology}

Research Design - Descriptive correlational research design was utilized in this study since the focus of the study is to describe quantitatively the responses of the two groups of respondents primarily the managers and rank-and-file employees of the ABC Semiconductor Company about the attainment of improved productivity, and to describe the flexible working arrangement amidst COVID 19 pandemic as well as its relationship.

Research Instrument - The proponent used survey questionnaire as research instrument in this study. A questionnaire is an instrument in research consisting of a series of questions for the purpose of collecting data and information from the respondents deemed necessary for the study. To measure the productivity of the employees, the Performance Appraisal Form existing used by the company was adopted. The second instrument used was a researcher-made instrument to measure the extent of implementation of the flexible work arrangements. It utilized a 4-Point Parameters from 4 being the "Highest Implemented" and 1 being the "Not Implemented" that will cover the normal operations and the development plans to be arranged flexible by both the employers and the employee in the implementation phase of its research.

Respondents of the Study - The respondents of the study were the samples to be stratified proportionally taken from each classification in Psi Technologies Inc. Using the RAOSOFT Sample Size Calculator, sample size of two-hundred seventy (270) composing 30 managers and 240 rank-and-file which is fifty point six percent $(50.6 \%)$ of the total population. This study employed stratified and purposive random sampling as for sampling procedure. The sampling method used purposive sampling which was a non-probabilistic sampling. Furthermore, the researcher also used stratified sampling in order to obtain respondents from different subgroup.

Data Gathering Procedure - In the conduct of the study. The researcher followed all research ethics protocols. Like submitting first all communications to the institution seeking permission to conduct the study and to gather necessary data from the target respondents. Second, following the ethics concerning data privacy act and the like by specifying explicitly in the cover letter of the questionnaire that voluntary participation is needed 
and no one is forcing anyone for its answers. Also, for whatever the data to be retrieved, it is for the sole purpose and for the utmost benefit of the research only. The second phase of the data gathering procedure after ethics protocol is the implementation phase of the Flexible Work Arrangements (FWA) that is to be done in a quarter. Retrieval phase is the final step in the data gathering procedure where all data to be collected will be tabulated, analyzed, and interpreted with the use of statistical tools aligned with the statement of the problems presented.

Treatment of Quantitative Data - To make sure that the data gathered were precisely treated; a statistical package for the social sciences (SPSS) software application was used. For the selection of the number of respondents, the RAOSOFT Sample Size Calculator was used to predetermine the sample size. Meanwhile, frequency distribution was used to determine the number of times the response falls or occurs under a given category. Also, simple mean was utilized to calculate the central tendency response of the member-respondents. Moreover, Pearson r Correlation Coefficient was used to measure the statistical relationship, or association, between two continuous variables. Furthermore, multiple linear regression was employed to analyze the relationship between a single dependent variable and several independent variables.

\section{Results and discussion}

Table 1.1 shows the Level of implementation of workers' flexible working arrangement as assessed by Department Manager and Rank-and-File in terms of Normal Operations. The general assessment was 2.68 which was verbally interpreted as Implemented. The indicator "I have the option to choose which schedule fits me best." has the highest computed composite mean of 2.95 which was verbally interpreted as Implemented. On the other hand, the indicators "From a 6-day work on site, it is shifted from 3 days' work-from-home and 3 days' work onsite." And "The attendance is monitored by logging in/out in a Microsoft/google form platform." had the lowest computer mean of 2.45 and were verbally interpreted as Partially Implemented. The results were related to the study of Joseph Mwendwa Musinga, Dr. Hellen W. Sang, Dr. Andrew Kipkosgei which found out Flexible working hours have recently gained a lot of attention from organizations and scholars as family-friendly policy.

\section{Table 1.1}

Level of implementation of workers' flexible working arrangement as assessed in terms of normal operations

\begin{tabular}{|c|c|c|c|c|c|c|}
\hline \multirow[t]{2}{*}{ Indicators in terms of Normal Operations } & \multicolumn{2}{|c|}{$\begin{array}{l}\text { Department } \\
\text { Manager }\end{array}$} & \multicolumn{2}{|c|}{$\begin{array}{l}\text { Rank \& } \\
\text { File }\end{array}$} & \multicolumn{2}{|c|}{ Composite } \\
\hline & $\mathrm{M}$ & VI & $\mathrm{M}$ & VI & $\mathrm{M}$ & VI \\
\hline On the FWA Scheduling & 2.96 & I & 2.45 & PI & 2.71 & I \\
\hline $\begin{array}{l}\text { From a } 6 \text {-day work on site, It is shifted from } 3 \text { days' work-from-home and } 3 \\
\text { days' work onsite. }\end{array}$ & 2.90 & I & 2.00 & PI & 2.45 & PI \\
\hline $\begin{array}{l}\text { From a three-shift schedule } 6 \mathrm{AM}-2 \mathrm{PM} / 2 \mathrm{PM}-10 \mathrm{PM} / 10 \mathrm{PM}-6 \mathrm{PM} \text { for } 6 \text { days, it } \\
\text { is congested to } 6 \mathrm{AM}-6 \mathrm{PM} / 6 \mathrm{PM}-6 \mathrm{AM} \text { for } 3 \text { days.. }\end{array}$ & 2.77 & I & 2.65 & I & 2.71 & I \\
\hline I have the option to choose which schedule fits me best. & 2.93 & I & 2.96 & I & 2.95 & I \\
\hline I have the option which office on site I can work from. & 2.60 & I & 2.62 & I & 2.61 & I \\
\hline $\begin{array}{l}\text { If WFH, I have the option which platform I have to work from (i.e., thru } \\
\text { emails, phone/mobile calls, google meet, Microsoft, or zoom platform) }\end{array}$ & 3.60 & FI & 2.00 & PI & 2.80 & I \\
\hline On the product/output from a FWA & 3.00 & I & 2.32 & PI & 2.66 & I \\
\hline $\begin{array}{l}\text { The attendance is monitored by logging in/out in a Microsoft/google form } \\
\text { platform. }\end{array}$ & 2.90 & I & 2.00 & PI & 2.45 & PI \\
\hline The output is to submit within the day of attendance. & 3.10 & I & 2.00 & PI & 2.55 & I \\
\hline The output is to submit before I return to work-on-site & 3.03 & I & 2.00 & PI & 2.52 & I \\
\hline There should be attached evidences in submitting the outputs in a FWA. & 3.07 & I & 2.80 & I & 2.94 & I \\
\hline The worker/employee needs to be online in the entire FWA schedule. & 2.90 & I & 2.82 & I & 2.86 & I \\
\hline GENERAL ASSESSMENT & 2.98 & I & 2.38 & I & 2.68 & I \\
\hline
\end{tabular}

Legend: 3.25 - 4.00 Fully Implemented (FI), 1.75 - 2.49 Partially Implemented (PI), 2.50 - 3.24 Implemented (I), $1.00-1.74$ Not Implemented (NI).

In addition, Table 1.2 shows the general assessment on the Level of implementation of workers' flexible working arrangement as assessed by Department Manager and Rank-and-File in terms of Development Plans which was 2.75 and was verbally interpreted as Implemented. All indicators were verbally interpreted as Implemented. Furthermore, the indicator "The institution invites high caliber and knowledgeable speakers 
Workers' flexible working arrangement and productivity in ABC semiconductor company

relative to work development and productivity" has the highest computed composite mean of 2.85 while the indicator "The institution provides at least two Trainings for individual development objectives every year" had the lowest computed composite mean of 2.66. Relative to this, Maheshwari and Vohra (2018) mentioned that training and learning activities for skills have usually been found to be used as a strong mentality for constructing and building. Training and development practices consistent with transition goals have been established to promote the successful design of training and development practices during the change by incorporating input from leaders.

\section{Table 1.2}

Level of implementation of workers' flexible working arrangement as assessed in terms of development plans

\begin{tabular}{|c|c|c|c|c|c|c|}
\hline \multirow[t]{2}{*}{ Indicators in terms of Development Plans } & \multicolumn{2}{|c|}{$\begin{array}{l}\text { Department } \\
\text { Manager }\end{array}$} & \multicolumn{2}{|c|}{ Rank \& File } & \multicolumn{2}{|c|}{ Composite } \\
\hline & $\mathrm{M}$ & VI & $\mathrm{M}$ & VI & $\mathrm{M}$ & VI \\
\hline Training and development & & & & & & \\
\hline $\begin{array}{l}\text { 1.1. The institution provides at least two Trainings for individual } \\
\text { development objectives every year. }\end{array}$ & 2.67 & I & 2.64 & I & 2.66 & I \\
\hline $\begin{array}{l}\text { 1.2. The institution invites high caliber and knowledgeable speakers } \\
\text { relative to work development and productivity. }\end{array}$ & 2.87 & I & 2.83 & I & 2.85 & I \\
\hline $\begin{array}{l}\text { 1.3. The institution made sure that the number of participants to be } \\
\text { accommodated in the training was appropriate. }\end{array}$ & 2.83 & I & 2.79 & I & 2.81 & I \\
\hline $\begin{array}{l}\text { 1.4. The institution gives equal opportunity for all the workers to attend in } \\
\text { the local, national, and international development whether face-to-face or } \\
\text { visual training. }\end{array}$ & 2.73 & I & 2.72 & I & 2.73 & I \\
\hline $\begin{array}{l}\text { 1.5. The institution makes sure that the training to provide will give } \\
\text { deeper understanding with the competence required in the company. }\end{array}$ & 2.70 & I & 2.70 & I & 2.70 & I \\
\hline GENERAL ASSESSMENT & 2.76 & I & 2.74 & I & 2.75 & I \\
\hline
\end{tabular}

Meanwhile, Table 2.1 shows the general assessment on the Extent of Worker's Productivity level in ABC Semiconductor Company in terms of Performance against Objectives which was 3.05 and was verbally interpreted as High. All indicators were verbally interpreted as High. In addition, the indicator "As an employees of Philippines Semiconductor Industry (PSi) Technologies Incorporated I apply the 5S and safety implementation" had the highest computed composite mean of 3.14 while the indicator "On-time delivery on withdrawn" has the lowest computed mean of 2.93. As support, Saxena and Srivastava (as cited in Hanasha, 2016) reported that work engagement has become one of the main challenges/activities that need to be well managed to fulfil organization objectives. They also demonstrated that there is a need to test its effect on performance outcomes.

Table 2.1

Extent of worker's productivity level in ABC semiconductor company in terms of performance against objectives

\begin{tabular}{|c|c|c|c|c|c|c|}
\hline \multirow{2}{*}{$\begin{array}{c}\text { Indicators in terms of Performance Against Objectives } \\
\text { As an employees of Philippines Semiconductor Industry (PSi) } \\
\text { Technologies Incorporated I... }\end{array}$} & \multicolumn{2}{|c|}{$\begin{array}{l}\text { Department } \\
\text { Manager }\end{array}$} & \multicolumn{2}{|c|}{ Rank-and-File } & \multicolumn{2}{|c|}{ Composite } \\
\hline & $\mathrm{M}$ & VI & $\mathrm{M}$ & VI & M & VI \\
\hline Have inventory accuracy & 3.13 & $\mathrm{H}$ & 2.92 & $\mathrm{H}$ & 3.03 & $\mathrm{H}$ \\
\hline FEFO/FIFO controls. & 3.13 & $\mathrm{H}$ & 3.07 & $\mathrm{H}$ & 3.10 & $\mathrm{H}$ \\
\hline On-time delivery on withdrawn & 2.97 & $\mathrm{H}$ & 2.88 & $\mathrm{H}$ & 2.93 & $\mathrm{H}$ \\
\hline Apply the $5 \mathrm{~S}$ and safety implementation. & 3.17 & $\mathrm{H}$ & 3.11 & $\mathrm{H}$ & 3.14 & $\mathrm{H}$ \\
\hline GENERAL ASSESSMENT & 3.10 & $\mathrm{H}$ & 2.99 & $\mathrm{H}$ & 3.05 & $\mathrm{H}$ \\
\hline
\end{tabular}

Legend: 3.25 - 4.00 Very High (VH), 1.75 - 2.49 Low (L), 2.50 - 3.24 High (H), 1.00 - 1.74 Very Low (VL).

However, Table 2.2 shows the Extent of Worker's Productivity level in ABC Semiconductor Company in terms of Values-based Behavior. The general assessment was 3.16 which was verbally interpreted as High. The indicator "As an employees of Philippines Semiconductor Industry (PSi) Technologies Incorporated I perform work with utmost business ethics, discipline, sincerity and dedication by doing the right things at all times and in all circumstances even when no one is watching/looking" under the sub-variable Integrity has the highest computed composite mean of 3.14 and was verbally interpreted as Very High. On the other hand, the indicator "Take accountability for commitment by admitting honestly to making mistakes, learning from and accepting 
Alzona, W. D. M., \& Villapando, M. A.

responsibility for the consequences of own actions" has the lowest computed composite mean of 3.06 and was interpreted as High.

Table 2.2

Extent of worker's productivity level in ABC semiconductor company in terms of values-based behavior

\begin{tabular}{|c|c|c|c|c|c|c|}
\hline \multirow{2}{*}{ Indicators in terms of Values-based Behavior } & \multicolumn{2}{|c|}{$\begin{array}{l}\text { Department } \\
\text { Manager }\end{array}$} & \multicolumn{2}{|c|}{ Rank \& File } & \multicolumn{2}{|c|}{ Composite } \\
\hline & $\mathrm{M}$ & VI & $\mathrm{M}$ & VI & $\mathrm{M}$ & VI \\
\hline INTEGRITY & 3.18 & $\mathrm{H}$ & 3.19 & $\mathrm{H}$ & 3.19 & $\mathrm{H}$ \\
\hline $\begin{array}{l}\text { As an employees of Philippines Semiconductor Industry (PSi) } \\
\text { Technologies Incorporated I... }\end{array}$ & & & & & & \\
\hline $\begin{array}{l}\text { Perform work with utmost business ethics, discipline, sincerity and } \\
\text { dedication by doing the right things at all times and in all } \\
\text { circumstances even when no one is watching/looking }\end{array}$ & 3.40 & $\mathrm{VH}$ & 3.47 & $\mathrm{VH}$ & 3.44 & $\begin{array}{l}\mathrm{V} \\
\mathrm{H}\end{array}$ \\
\hline $\begin{array}{l}\text { Take accountability for commitment by admitting honestly to } \\
\text { making mistakes, learning from and accepting responsibility for the } \\
\text { consequences of own actions. }\end{array}$ & 3.07 & $\mathrm{H}$ & 3.05 & $\mathrm{H}$ & 3.06 & $\mathrm{H}$ \\
\hline $\begin{array}{l}\text { Complies with Company policies and regulations, and maintains } \\
\text { confidentiality and professionalism in all business dealings. }\end{array}$ & 3.07 & $\mathrm{H}$ & 3.06 & $\mathrm{H}$ & 3.07 & $\mathrm{H}$ \\
\hline CUSTOMER FOCUS & 3.16 & $\mathrm{H}$ & 3.11 & $\mathrm{H}$ & 3.14 & $\mathrm{H}$ \\
\hline $\begin{array}{l}\text { Collaborates with customers (internal/external) to achieve shared } \\
\text { goals. }\end{array}$ & 3.10 & $\mathrm{H}$ & 3.06 & $\mathrm{H}$ & 3.08 & $\mathrm{H}$ \\
\hline $\begin{array}{l}\text { Provides compelling value-add services and solutions that exceed } \\
\text { customers' expectation, and drives zero defect. }\end{array}$ & 3.20 & $\mathrm{H}$ & 3.18 & $\mathrm{H}$ & 3.19 & $\mathrm{H}$ \\
\hline $\begin{array}{l}\text { Manages customers with professionalism and respect by anticipating } \\
\text { their needs and responding to their concerns with timeliness }\end{array}$ & 3.17 & $\mathrm{H}$ & 3.10 & $\mathrm{H}$ & 3.14 & $\mathrm{H}$ \\
\hline CONCERN FOR OTHERS & 3.18 & $\mathrm{H}$ & 3.11 & $\mathrm{H}$ & 3.15 & $\mathrm{H}$ \\
\hline Helps maintain a safe, healthy and secured working environment. & 3.17 & $\mathrm{H}$ & 3.10 & $\mathrm{H}$ & 3.14 & $\mathrm{H}$ \\
\hline $\begin{array}{l}\text { Inspires confidence, coaches and empowers by respecting people } \\
\text { and diversity, and embraces a culture of learning and development. }\end{array}$ & 3.17 & $\mathrm{H}$ & 3.10 & $\mathrm{H}$ & 3.14 & $\mathrm{H}$ \\
\hline $\begin{array}{l}\text { Encourages volunteerism by sharing talents, time, resources and } \\
\text { blessings, and engages in corporate social responsibility initiatives }\end{array}$ & 3.20 & $\mathrm{H}$ & 3.13 & $\mathrm{H}$ & 3.17 & $\mathrm{H}$ \\
\hline EXCELLENCE & 3.19 & $\mathrm{H}$ & 3.10 & $\mathrm{H}$ & 3.15 & $\mathrm{H}$ \\
\hline $\begin{array}{l}\text { Constantly raises the bar to create standards of excellence and sets } \\
\text { examples for others to follow }\end{array}$ & 3.20 & $\mathrm{H}$ & 3.11 & $\mathrm{H}$ & 3.16 & $\mathrm{H}$ \\
\hline $\begin{array}{l}\text { Actively contributes expertise and works harmoniously with the } \\
\text { team to deliver superior performance, world-class products and } \\
\text { services, and to achieve best results. }\end{array}$ & 3.20 & $\mathrm{H}$ & 3.12 & $\mathrm{H}$ & 3.16 & $\mathrm{H}$ \\
\hline $\begin{array}{l}\text { Commits to continuous learning and development by exploring new } \\
\text { ways of doing things through innovative ideas and solutions by } \\
\text { taking risks and considering failures as learning experience.. }\end{array}$ & 3.17 & $\mathrm{H}$ & 3.06 & $\mathrm{H}$ & 3.13 & $\mathrm{H}$ \\
\hline GENERAL ASSESSMENT & 3.18 & $\mathrm{H}$ & 3.13 & $\mathrm{H}$ & 3.16 & $\mathrm{H}$ \\
\hline
\end{tabular}

Legend: 3.25 - 4.00 Very High (VH), 1.75 - 2.49 Low (L), 2.50 - 3.24 High (H), $1.00-1.74$ Very Low (VL).

According to the study of Gleeson (2017), some productivity performance on values-based behaviors which includes that leadership focused on values is linked to guiding the team and measuring success - both the leader's own and the team's - based more on the collection of values of the company rather than concrete indicators and milestones. Leaders still have to supervise the capacity of their team member to succeed and be responsible for their role in the success of the task, but assessments based on values should not be an afterthought.

Table 2.3

Extent of worker's productivity level in ABC semiconductor company in terms of attendance and punctuality

\begin{tabular}{|c|c|c|c|c|c|c|}
\hline \multirow{2}{*}{$\begin{array}{l}\text { Indicators in terms of Attendance and Punctuality } \\
\text { As an employees of Philippines Semiconductor Industry (PSi) } \\
\text { Technologies Incorporated I have... }\end{array}$} & \multicolumn{2}{|c|}{$\begin{array}{l}\text { Department } \\
\text { Manager }\end{array}$} & \multicolumn{2}{|c|}{ Rank-and-File } & \multicolumn{2}{|c|}{ Composite } \\
\hline & $\mathrm{M}$ & VI & $\mathrm{M}$ & VI & $\mathrm{M}$ & VI \\
\hline $\begin{array}{l}\text { No Unauthorized absence; No ML; With SL; Did not exceed } \\
\text { leave credits for the year }\end{array}$ & 3.43 & $\mathrm{VH}$ & 3.36 & $\mathrm{VH}$ & 3.40 & $\mathrm{VH}$ \\
\hline Submit the reports on or before the deadline. & 3.40 & VH & 3.29 & VH & 3.35 & $\mathrm{VH}$ \\
\hline No tardiness. & 3.47 & VH & 3.28 & $\mathrm{VH}$ & 3.38 & $\mathrm{VH}$ \\
\hline GENERAL ASSESSMENT & 3.43 & $\mathrm{VH}$ & 3.31 & VH & 3.37 & $\mathrm{VH}$ \\
\hline
\end{tabular}

20 Consortia Academia Publishing (A Partner of Tourism Educators and Movers of the Philippines) 
As shown in Table 2.3, the general assessment on the Extent of Worker's Productivity level in ABC Semiconductor Company in terms of Attendance and Punctuality was 3.37 which was verbally interpreted as Very High. All indicators were verbally interpreted as Very High. In addition, the indicator "As an employees of Philippines Semiconductor Industry (PSi) Technologies Incorporated I have no Unauthorized absence; No ML; With SL; Did not exceed leave credits for the year" has the highest computed composite mean of 3.40 while the indicator "Submit the reports on or before the deadline" has the lowest computed mean of 3.37. As reflected by Smith (2018), strong attendance, however, means more than just putting the body in the seat. An employee must be emotionally and mentally present to cultivate a work ethic to be prepared to take on any obstacles in the workplace. Employees' success can be nurtured by getting there on time and ready to work.

\section{Table 3.1}

Test of difference on the assessment of manager and rank-and-file with regard to flexible working arrangement

\begin{tabular}{|c|c|c|c|c|c|c|c|c|}
\hline \multicolumn{2}{|c|}{ Sub-variables } & \multirow{2}{*}{$\begin{array}{l}\begin{array}{l}\text { Sum of } \\
\text { squares }\end{array} \\
9.441\end{array}$} & \multirow{2}{*}{$\frac{\mathrm{df}}{1}$} & \multirow{2}{*}{$\begin{array}{c}\text { Mean } \\
\text { square }\end{array}$} & \multirow[t]{2}{*}{ F Ratio } & \multirow[t]{2}{*}{ Sig. } & \multirow[t]{2}{*}{ Remarks } & \multirow[t]{2}{*}{ Decision } \\
\hline \multirow{3}{*}{ Normal operations } & Between Groups & & & & & & & \\
\hline & Within Groups & 7.994 & 268 & 9.441 & \multirow[t]{2}{*}{316.500} & \multirow[t]{2}{*}{.000} & \multirow[t]{2}{*}{ Significant } & \multirow[t]{2}{*}{ Reject $\mathrm{H}_{\mathrm{o}}$} \\
\hline & Total & 17.435 & 269 & & & & & \\
\hline \multirow{2}{*}{$\begin{array}{l}\text { Development } \\
\text { Plans }\end{array}$} & Between Groups & .017 & 1 & .017 & \multirow[b]{2}{*}{.086} & \multirow[b]{2}{*}{.770} & \multirow{2}{*}{$\begin{array}{c}\text { Not } \\
\text { Significant }\end{array}$} & \multirow[b]{2}{*}{ Accept $\mathrm{H}_{\mathrm{C}}$} \\
\hline & Within Groups & 52.138 & 268 & .195 & & & & \\
\hline
\end{tabular}

Level of significance 0.05

Furthermore, table 3.1 shows the Test of Significant Difference on the Assessment of the Department Manager and Rank-and-File with regard to the Level of Implementation of Workers' Flexible Working Arrangement. The result revealed that the generated computed probability value Development Plans was .770 which was greater than the level of significance of 0.05 ; thus, the null hypothesis is accepted. Therefore, there is no significant difference between the responses of the two groups of respondents on the above mentioned variable. In contrary, the generated computed probability value Normal Operation was .000 which was less than the level of significance of 0.05 ; thus, the null hypothesis is rejected. Therefore, there is significant difference between the responses of the two groups of respondents on the above mentioned variable. According to the article published by shrm.org (2021) management is distinguished as the level of supervision between the rank-and-file employees and organizational leaders. Residing between effective leadership and efficient employees, effective managers are critical to organizational success. Different paths to becoming a manager exist-either through the ranks or through outside accomplishments. Managers must have certain knowledge, skills and abilities (KSAs) to be able to achieve organizational goals and engage employees. Lacking these KSAs, managers will need basic or advanced training, depending on their place within an organization.

Table 3.2

Test of difference on the assessment of manager and rank-and-file with regard to productivity level

\begin{tabular}{|c|c|c|c|c|c|c|c|c|}
\hline \multicolumn{2}{|c|}{ Sub-variables } & \multirow{2}{*}{$\begin{array}{c}\begin{array}{c}\text { Sum of } \\
\text { squares }\end{array} \\
.301 \\
57.816 \\
58.117\end{array}$} & \multirow{2}{*}{$\begin{array}{c}\text { df } \\
1 \\
268 \\
269\end{array}$} & \multirow{2}{*}{$\begin{array}{c}\begin{array}{c}\text { Mean } \\
\text { square }\end{array} \\
301 \\
.216\end{array}$} & \multirow{2}{*}{$\begin{array}{c}\begin{array}{c}F \\
\text { Ratio }\end{array} \\
1.395\end{array}$} & \multirow{2}{*}{$\begin{array}{l}\text { Sig. } \\
.239\end{array}$} & \multirow{2}{*}{$\begin{array}{c}\text { Remarks } \\
\text { Not } \\
\text { Significant }\end{array}$} & \multirow{2}{*}{$\begin{array}{c}\text { Decision } \\
\text { Accept } \\
\mathrm{H}_{\mathrm{o}}\end{array}$} \\
\hline $\begin{array}{c}\text { Performance against } \\
\text { objectives }\end{array}$ & $\begin{array}{c}\text { Between Groups } \\
\text { Within Groups } \\
\text { Total }\end{array}$ & & & & & & & \\
\hline Values-based behavior & $\begin{array}{c}\text { Between Groups } \\
\text { Within Groups } \\
\text { Total }\end{array}$ & $\begin{array}{c}.060 \\
31.381 \\
31.441\end{array}$ & $\begin{array}{c}1 \\
268 \\
269\end{array}$ & $\begin{array}{l}.060 \\
.117\end{array}$ & .510 & .476 & $\begin{array}{c}\text { Not } \\
\text { Significant }\end{array}$ & $\begin{array}{c}\text { Accept } \\
\mathrm{H}_{\mathrm{o}}\end{array}$ \\
\hline $\begin{array}{l}\text { Attendance and } \\
\text { Punctuality }\end{array}$ & $\begin{array}{c}\text { Between Groups } \\
\text { Within Groups } \\
\text { Total }\end{array}$ & $\begin{array}{c}.417 \\
75.705 \\
76.122\end{array}$ & $\begin{array}{c}1 \\
268 \\
269\end{array}$ & $\begin{array}{l}.417 \\
.282\end{array}$ & 1.477 & .225 & $\begin{array}{c}\text { Not } \\
\text { Significant }\end{array}$ & $\begin{array}{c}\text { Accept } \\
\mathrm{H}_{\mathrm{o}}\end{array}$ \\
\hline
\end{tabular}

Table 3.2 shows the Test of Significant Difference on the Assessment of the Department Manager and Rank-and-File with regard to The Extent of Worker's Productivity level in ABC Semiconductor company. The generated computed probability values Performance against Objectives, Values-based behavior, and Attendance 
Alzona, W. D. M., \& Villapando, M. A.

and Punctuality was $.239, .476$ and .225 respectively which were greater than the level of significance of 0.05 ; thus, the null hypothesis is accepted. Therefore, there is no significant difference between the responses of the two groups of respondents on the above mentioned variables. According to the article published by shrm.org (2021), managers may receive inspiration and direction from leaders. Yet managers are charged with the application of aspirational and strategic principles to the day-to-day process of getting the job done, done right and done efficiently. Managers' critical function is to translate leadership and shareholder objectives (or create them on their own when they do not come from above) into legal and effective actions to achieve those objectives.

\section{Table 4}

Test of significant relationship between workers' flexible working arrangements and productivity

\begin{tabular}{|c|c|c|c|c|c|}
\hline $\begin{array}{l}\text { Workers' Flexible } \\
\text { Working } \\
\text { Arrangement }\end{array}$ & $\begin{array}{l}\text { Extent of Worker's } \\
\text { Productivity }\end{array}$ & $\mathrm{r}$ value & $P$ value & Remarks & Decision \\
\hline \multirow{3}{*}{ Normal operations } & $\begin{array}{c}\text { Performance against } \\
\text { objectives }\end{array}$ & $.120 *$ & .049 & Significant & Reject $\mathrm{H}_{\mathrm{o}}$ \\
\hline & Values-based behavior & .036 & .557 & Not Significant & Accept $\mathrm{H}_{\mathrm{o}}$ \\
\hline & Attendance and Punctuality & .034 & .576 & Not Significant & Accept $\mathrm{H}_{\mathrm{O}}$ \\
\hline \multirow{3}{*}{ Development Plans } & $\begin{array}{c}\text { Performance against } \\
\text { objectives }\end{array}$ & $.127 *$ & .037 & Significant & Reject $\mathrm{H}_{\mathrm{o}}$ \\
\hline & Values-based behavior & $.171 * *$ & .005 & Significant & Reject $\mathrm{H}_{\mathrm{o}}$ \\
\hline & Attendance and Punctuality & .044 & .474 & Not Significant & Accept $\mathrm{H}_{\mathrm{o}}$ \\
\hline
\end{tabular}

**Correlational at the level 0.01, *Correlational at the level 0.05(Two-tailed).

Meanwhile, table 4 revealed that the $r$ value on level of implementation of workers' flexible working arrangements and the extent of worker's productivity level $(.120, .127$, and .171) were interpreted as with very weak positive correlation and the computed probability values $.049, .037$, and .005 were less than the level of significant $(p<0.05)$; thus, the null hypothesis is rejected. The result shown that there is significant relationship between the Level of Implementation of Workers' Flexible Working Arrangements and Productivity in ABC Semiconductor Company. Mwebi and Kadaga (as cited in Austin-Egole et al., 2020) studied the effects of flexi-time work arrangement on employee performance and their findings revealed that flexi-time work arrangement is positively related to employee performance. Hashim et al. (2017) study on impact of time flexibility on staff performance of the Government Colleges of Management Sciences in Peshawar found out that there is a significant relationship between time flexibility and employee performance. Flexibility has a positive impact on employee performance.

Table 5

Regression analysis on flexible working arrangements towards productivity in terms of values-based behavior

\begin{tabular}{|c|c|c|c|c|c|c|c|}
\hline \multirow{2}{*}{ Model } & \multicolumn{2}{|c|}{$\begin{array}{c}\text { Unstandardized } \\
\text { Coefficients }\end{array}$} & \multirow{2}{*}{$\begin{array}{c}\text { Standardized } \\
\text { Coefficients } \\
\text { Beta }\end{array}$} & \multirow{2}{*}{$\mathrm{T}$} & \multirow{2}{*}{ Sig. } & \multirow{2}{*}{ Remarks } & \multirow{2}{*}{ Decision } \\
\hline & B & Beta & & & & & \\
\hline (Constant) & 3.339 & .229 & & 14.610 & .000 & & \\
\hline Normal operations & .068 & .081 & .051 & .837 & .404 & $\begin{array}{c}\text { Not } \\
\text { Significant }\end{array}$ & Accept $\mathrm{H}_{\mathrm{o}}$ \\
\hline Development Plans & -.136 & .047 & -.175 & -2.904 & .004 & Significant & Reject $\mathrm{H}_{\mathrm{o}}$ \\
\hline
\end{tabular}

Dependent Variable: Values-based behavior.

Moreover, Table 5 shows the Regression Analysis on the Impact the Flexible Working Arrangements Specifically Development Plans to Workers' productivity in ABC Semiconductor company in terms of Values-based behavior. The generated probability value of efficiency was .004 which was less than the level of significance $(p<.05)$, thus the null hypothesis is rejected. According to Arinanye (2015) area in the training and development arena, employee performance may be impacted by diverse factors, it may be due to leaders' attitude, personal concerns, roles, responsibilities, norms, and standards. He also provided other factors, such as lack of proper equipment and skills, high work load, inadequate more clerical hold, non-attendance of key human 
resources, insufficient routine of managers, undecided objectives or performance standards, deficient statement within the organization, pressure from co-workers to limited presentation, and lack of ability to get things done more. There are additional factors impacting employee performance. The findings showed that that the implementation of Flexible Working Arrangement Specifically Development Plans has significant effect on the Workers' productivity in terms of Values-based Behavior. The implementation of FWA is contributory to the work productivity of the employees.

Based on the result of the study, action plan was proposed to improve the Flexible Working Arrangement Implementation of the ABC Semiconductor company by giving emphasis on the key areas where execution is bit low and to encourage its employees to perform their duties in the outmost of their ability through different programs and activities. An action plan was proposed to improve the Flexible Working Arrangement Implementation of the ABC Semiconductor company by giving emphasis on the key areas where execution is bit low and to encourage its employees to perform their duties in the outmost of their ability through different programs and activities.

\section{Conclusions and directions for future use}

Based on the results of this study, it can be concluded that consideration of flexible work arrangements aspects that pertains to employees, can greatly influence the employee satisfaction in shared services. Based on the above-mentioned findings of the study, the following conclusions have been derived:

$>\quad$ That ABC Semiconductor company evidently implemented workers' flexible working arrangement in the Normal Operations and Development Plans. The 2020 COVID-19 pandemic has placed flexible work arrangements in the spotlight. With many companies issuing stay-at-home orders and allowing only essential businesses to keep their physical locations open, unprepared employers were forced to implement flexible work options on the fly. Learning and development is vital among the various HRM practices which helps employees to keep them update with the requisite knowledge, skills and attitudes (KSAs) necessary for innovation.

$>$ That there is a high worker's productivity level in in ABC Semiconductor as to employees Performance against Objectives and Values-based Behavior and very high productivity level as to Attendance and Punctuality. Employee work engagement is one of the main business priorities for organizational executives. Engagement depends on employees' perceptions and evaluations of their working experience, including their employer, organizational leaders, the job itself, and work environment. Through these, employees act based on acquired and innate values-based behavior.

$>\quad$ That the Department Manager and Rank-and-File have the same perception with regards to the Level of Implementation of Workers' Flexible Working Arrangement specifically development plans and Extent of Worker's Productivity level but not on normal operation.

$>$ That implementation of workers' flexible working arrangements is associated or connected to the extent of worker's productivity level in terms of performance against objectives and values-based behavior. The higher the implementation of the workers' flexible working arrangements, the higher the worker's productivity level and vice versa.

$>\quad$ That the implementation of Flexible Working Arrangement Specifically Development Plans has significant effect on the Workers' productivity in terms of Values-based Behavior. The implementation of FWA is contributory to the work productivity of the employees.

$>\quad$ That there is a need to have Working Arrangement Program or Work at Home (WAH) Set-Up Policy which allows employees to work from home only if their job duties permit it. For example, people who are obliged to come in direct physical contact with customers are not eligible to telecommute 
under this policy. But employees who carry out most of their work on a computer can occasionally work off-site without compromising productivity and job satisfaction.

\subsection{Recommendations}

The following are the recommendations offered by the researcher based on the above-mentioned findings and conclusions.

$>$ Company and managers may provide more flexible work arrangements considerations even without pandemic such as Normal Operation and Development Plans. Flexible working arrangements is important in increasing employee productivity in the company.

$>$ Organization may diagnose employees flexible work arrangement practices needs and develop practical solutions by implementing it in a long run or permanent basis to be able to achieve business goals and increase workers' productivity.

$>$ Management may consider implementing flexible working arrangements because it has positive and significant correlation with employee productivity. It is important to provide suitable flexible working arrangements in a long-term plan.

> Management may review existing flexible work arrangements with employees to check its applicability, advantages and disadvantages.

$>$ Management may adopt the proposed action plan to improve the Flexible Working Arrangement Implementation of the $\mathrm{ABC}$ Semiconductor company and to encourage its employees to perform their duties in the outmost of their ability through different programs and activities.

$>$ Further researches on the permanent flexible arrangement may be pursued in order to identify suitable arrangement when face-to-face is limited without compromising employees' productivity and satisfaction.

\section{References}

Anderman, E. M., \& Sinatra, G. M. (2012). The challenges of teaching and learning about science in the 21. ERIC Search, 48(1), 1-50.

Arinanye, R. T. 2015). Organizational factors affecting employee performance at the College of Computing and Information Sciences (COCIS), Makerere University, Kampala, Uganda (Unpublished master dissertation). Uganda Technology and Management University, Kampala, Uganda.

Armstrong, M., \& Taylor, S. (2014). Armstrong's handbook of human resource management practice (13 ed.). London: Michael Armstrong.

Aten, J. (2020). Workers don't want to return to offices. start preparing now a new survey from IBM shows that, for a majority of Americans, remote work is here to stay. Retrieved form https://www.inc.com/jasonaten/americans-want-to-keep-working-remotely-even-after-office-reopens.ht $\underline{\mathrm{ml}}$

Augustino, K. R. (2017). An assessment on the impact of employees' absenteeism on performance in local government authorities: A case of Busokelo District Council. https://core.ac.uk/download/pdf/79425376.pdf

Austin-Egole, I, \& Iheriohanma, E. B. J., \& Chinedu, N. (2020). Flexible working arrangements and organizational performance: An overview. https://doi.org/10.9790/0837-2505065059

Bakshi, G. (2020). Remote Work Series Part 3: How to measure productivity when working from home. Retrieved from https://www.netsolutions.com/insights/how-to-measure-productivity-when-working-from-home/

Bowdoin. (2018). Attendance and punctuality. An Article in Bowdoin.edu website. Retrieved from 
Workers' flexible working arrangement and productivity in ABC semiconductor company

https://www.bowdoin.edu/hr/employee-handbook/employment/attendance-punctuality.html

Cole, G. (2006). Flexibility and the workplace: The battle to control working time. Managerial Law, 48(6), 536-540.

Elnaga, A., \& Imran, A. (2013). The Effect of Training on Employee Performance. European Journal of Business and Management, 5(4), 137-147

Gainey, T. \& Clenney, B. (2006). Flextime and telecommuting: Examining individual perceptions. Southern Business Review, 32(1), 13-22.

Gleeson, B. (2017). How values-based leadership transforms organizational cultures. https://www.inc.com/brent-gleeson/how-values-based-leadership-transforms-organizationalcultures.htm 1

Go Business. (2020). Take care of your employees. Retrieved from https://covid.gobusiness.gov.sg/faq/resumption/wfh/

Hall, L., \& Atkinson, C. (2006). Improving working lives: flexible working and the role of employee control. Employee Relations, 28(4), 374-386.

Hammer, L., \& Alley, L. (2020). Why leaders must show empathy during the coronavirus pandemic. A Public Health Write-up on The National Interest. Retrieved from https://nationalinterest.org/blog/buzz/whyleaders-must-show-empathy-during-coronavirus-pandemic

Hanaysha, J. (2016). Improving employee productivity through work engagement: Evidence from higher education sector. Management Science Letters, 6, 61-70. https://doi.org/10.5267/j.msl.2015.11.006

Harcourt, H. M. (2020). Functions of managers. Cliffnotes principles of management. Retrieved from https://www.cliffsnotes.com/study-guides/principles-of-management/the-nature-of-management/functio nsof-managers

Hashim, M., Ullah, M., \& Khan, M. A. (2017). Impact of time flexibility on employees' performance: A study of Teaching Faculty in Government Colleges of Management Sciences, Peshawar, City. University Research Journal, 206-207

Hendrikz, K., \& Engelbrecht, A. S. (2019). The principled leadership scale: An integration of value-based leadership. Journal of Industrial Psychology, 45, a1553. https://doi.org/10.4102/sajip.v45i0.1553

Hoefling, T. (2017). Working Virtually: Transforming the Mobile Workplace.

Holmes, A. C., \& Oldham, K. W. (2019). Socially just training and development for housing employees and leaders. New Directions for Student Services, 168, 41-50. https://doi.org/10.1002/ss.20330

Jain, S. (2019). HR Solutions for Excellence in Training \& Development. Society Publishing.

John, A., Nisbett, N., Barnett, I., Avula, R., \& Menon, P. (2020). Factors influencing the performance of community health workers: A qualitative study of Anganwadi Workers from Bihar, India.

Kessler, F. (2017). IBM, remote-work pioneer, is calling thousands of employees back to the office. Retrieved from https://qz.com/924167/ibm-remote-work-pioneer-is-calling-thousands-of-employees-back-to-the-office/

Locke, E. A., \& Latham, G. P. (2006). New directions in goal-setting theory. Current Directions in Psychological Science, 15(5), 265-268.

Lott, Y. (2020). Does flexibility help employees switch off from work? Flexible working -time arrangements and cognitive work-to-home spillover for women and men in Germany. Social Indicators Research, 151(2), 471-494.

Maheshwari, S., \& Vohra, V. (2018). Role of training and development practices in implementing change. International Journal of Learning and Change, 10(2), 131-162. https://doi.org/10.1504/IJLC.2018.090911

McDonald, P., Guthrie, D., Bradley, L., \& Shakespeare-Finch, J. (2005). Investigating work-family policy aims and employee experiences. Employee Relations, 27(5), 478-494.

McEwen, D. (2011). Employee engagement: A systemic approach to high employee engagement. Retrieved from http://www.cgnglobal.com/sites/default/files/Employee_Engagement_CGN\%20Global.pdf

McKinsey \& Company. (2020). COVI19: Implications for Business. A vaccine breakthrough and how companies are thinking about purpose: here's the latest from McKinsey's Research. Retrieved from 
Alzona, W. D. M., \& Villapando, M. A.

https://www.mckinsey.com/business-functions/risk/our-insights/covid-19-implications-for-business

McKinsey \& Company. (2020). What to make of the promising news on COVID-19 vaccines and new CEO insights on leading through the pandemic: here's this week's update. Retrieved from https://www.mckinsey.com/business-functions/risk/our-insights/covid-19-implications-for-business

Melbourne, S. (2008). May, Flexible thinking. HR Monthly, pp. 44-45

Mwebi, M. B., \& Kadaga, M. N. (2015). Effects of flex-time work arrangement on employee performance in Nairobi CBD Commercial Banks. International Journal of Novel Research in Marketing Management and Economics, 2(3), 111-121.

Nadeem, S., \& Henry, C. (2003). Power dynamics in the long-term development of employee-friendly flexible working. Women in Management Review, 18(1/2), 32-49.

Nanzushi, C. (2015), A research project of Master Business Administration, University of Nairobithe: Effect of workplace environment on employee performance in the mobile telecommunication firms in Nairobi City Country. Retrieved from https://pdfs.semanticscholar.org

Neill, J. O. (2018). What's ahead for a Semiconductor Industry? Industry week best plants statistical profile. Retrieved from https://www.industryweek.com/technology-and-iiot/article/22026855/whats-ahead-for-thesemiconducto r-industry

O'Connell, B. (2020). How managers are handling performance reviews during COVID19. A Write-up in SHRM. Retrieved from https://www.shrm.org/resourcesandtools/hr-topics/people-managers/pages/performancereviews-duringcoronavirus

PSI Technologies Ltd. (2018). Company: Our story. Retrieved from https://www.psitechnologies.com/company/

Reese, S. R. (2017). Leadership core values and beliefs are keys to greatness. Center for Management and Organization Effectiveness. Retrieved from https://cmoe.com/blog/great-leaders-have-specific-beliefsandcore-values/

Rothmann, S., \& Storm, K. (2003). Work engagement in the South African Police Service. Retrieved from http://www.sajip.co.za/index.php/sajip/article/view/925/973

Saxena, V., \& Srivastava, R. K. (2015). Impact of employee engagement on employee performance-Case of manufacturing sectors. International Journal of Management Research and Business Strategy, 4(2), 139-174.

Secret, M. (2000). Identifying the family, job, and workplace characteristics of employees who use work-family benefits. Family Relations, 49(2), 217-226.

Sharafizad, F., Paull, M., \& Omari, M. (2011). Flexible work arrangements: Accessibility in a university environment. Australian Universities Review, 53(2), 43-49.

Shockley, K. M., \& Allen, T. D. (2007). When flexibility helps: Another look at the availability of FWAs and work-family conflict'. Journal of Vocational Behavior, 71(3), 479-493.

Smith, J. (2018). Importance of attendance in work ethics. Retrieved from https://work.chron.com/importance-attendance-work-ethics-5082.html

Truity (2020). Semi-conductor processor. Retrieved from https://www.truity.com/career-profile/semiconductorprocessor

Uglanova, E., \& Dettmers, J. (2018). Sustained effects of flexible working time arrangements on subjective well-being. Journal of Happiness Studies, 19(6), 1727,1748.

Valoir. (2020). Working at home is working. Retrieved from https://valoir.com/blog-1/working-at-home-is-working

Villaraza \& Angangco. (2020). Unpacking the work-from-home concept in the Philippine Labor Law. A write up in Lexology. Retrieved from https://www.lexology.com/library/detail.aspx?g=f9cba3a1-f21e-40ed-b448a19fa1ffb67c

Walters, K., \& Rodriguez, J. (2017). The importance of training and development in employee performance and evaluation. PLoS ONE, 15(11), e0242460. https://doi.org/10.1371/journal.pone.0242460

Waters, M., \& Bardoel, E. (2006). Work-family policies in the context of higher education: Useful or symbolic?

26 Consortia Academia Publishing (A Partner of Tourism Educators and Movers of the Philippines) 
Workers' flexible working arrangement and productivity in ABC semiconductor company

Asia Pacific Journal of Human Resources, 44(1), 67-82.

Weaver, K. (2016). Goal setting theory overview from work attitudes and job motivation home page. Retrieved form https://wikispaces.psu.edu/display/PSYCH484/6.+Goal+Setting+Theory

Wilken, H., (2020). Managing a performance evaluations during a pandemic. A Write-up in Association for Talent Development. Retrieved from https://www.td.org/insights/managing-performance-evaluations-during-apandemic

Worklogic. (2020). The benefits of flexible working. Retrieved from https://www.worklogic.com.au/employment-policies/the-benefits-of-flexible-working/ 
Alzona, W. D. M., \& Villapando, M. A.

28 Consortia Academia Publishing (A Partner of Tourism Educators and Movers of the Philippines) 